\title{
Narrating "Home": Experiences of German Expellees after the Second World War
}

\author{
VANESSA HUGHES
}

\section{Abstract}

This article explores the experiences of forced displacement through the narratives of expellees in Germany after the Second World War. It considers how disruptions of "home" over time and space have led to constant deconstructing and reconstructing of home. Based on autobiographical interviews, this article argues that home is multidimensional and contradictory, changing over time and through experiences, becoming simultaneously connected to a specific place and time while transcending this rootedness. This continuous contestation of home has led expellees to form an imagined, idealized, and romanticized notion of their Heimat that exists in memory and is combined with their current home, Zuhause.

\section{Résumé}

Cet article étudie les expériences de déplacement forcé à travers les récits des expulsés en Allemagne à la suite de la Deuxième Guerre mondiale. Il considère le processus par lequel les perturbations dans l'idée d'un "chez-soi» dans le temps et l'espace ont mené à une déconstruction et reconstruction constante de cette notion. En se basant sur des entrevues autobiographiques, cet article avance que l'idée de "chez-soi» est multidimensionnelle et contradictoire, se transformant à travers le temps et les expériences, s'attachant à un lieu et temps particulier et en même temps évoluant au-delà de cet enracinement. Cette contestation continuelle de l'idée de "chez-soi» a mené les expulsés à former une notion imaginée, idéalisée et romantique de leur Heimat qui existe dans la mémoire et qui est conjuguée avec l'idée de leur Zuhause, leur chez-soi actuel.

\section{Introduction}

There were twelve million German refugees and expellees in Germany after the Second World War. This was one of the biggest movements of people in Europe's recent history, yet little is known about how individuals experienced it. ${ }^{1}$

In this article my aim is to explore how expellees experienced their expulsion and subsequent repatriation, and how this influenced their understanding of "home." Following Malkki, I will examine their experiences to "question the notion of identity as a historical essence rooted in particular places, or as a fixed and identifiable position in a universalizing taxonomic order."2 Broadly speaking, their common experience was an expulsion from their childhood home and being placed in a "home by chance." 3 Disruptions of "home" forced them to continuously negotiate meanings of home, both materially and symbolically.

Among the narratives in this research three main chronological phases of "home" emerged. The first is dominated by a sense of "loss," the second phase by "itinerancy," and the final phase is "settlement." These three phases will be explored in this article.

These experiences of "home" contributed to a distinct construction of what "home" means to expellees. Previous studies on this topic found that expellees make a clear distinction between Zuhause (at home) and Heimat (homeland), ${ }^{4}$ where ties to the "homeland" are maintained, and the new home is only reluctantly accepted. 5 Such discourses are present in personal and collective narratives. 6 "Home" here is a multidimensional concept, which includes personal and social aspects as well as physical, emotional, material, and symbolic meanings. Furthermore, "home" can be contradictory and ambivalent, fixed and yet without boundaries. ${ }^{7}$

By analyzing the three phases of "home" in the narratives of expellees, my aim is to understand what "home" and 
"homeland" means to them, how these phases have influenced expellees' construction of "home," and to what extent recent theories can explain these constructions. In this article I will first discuss the concept of home and the historical context of this article. I will then explore the three phases of "home" as narrated by the expellees and finally evaluate how they contribute to a conceptualization of "home"-in short how displacement, deterritorialization, and exile shape the construction of "home."

\section{What Is the Meaning of "Home"?}

Conceptualizing home is complex. Traditionally home was viewed as fixed and bounded, linked to the assumption of a natural association between people, culture, and territory, ${ }^{8}$ connected with feelings of security, familiarity, and privacy, and gendered as female, rather than the (male) public sphere. More recently, interdisciplinary, feminist, and transnational approaches have challenged this notion of home. This included decoupling the private sphere from naturally being gendered as female, disassociating home from its physical locality, deconstructing its identity-place unity, and thus exposing its social and cultural construction. ${ }^{9}$ For example, in her study of elderly Bengalis in London, Gardner found that their understanding of home is "fluid: a set of practices, memories and myths." 10 The meaning of home to an individual can thus change according to gender and stage in the life-course, and depends on cultural, historical, economic, and political context. ${ }^{11}$ Furthermore, home is a concept that is culturally and ideologically influenced, inscribed with personal meanings and emotions. ${ }^{12}$ Given that in migration or displacement, contextual factors and the material dwelling change, this becomes an appropriate site in which to study "home."

Important contributions to this field and relevant to this article have emerged from anthropologists working on transnationalism. ${ }^{13}$ In their Migrants of Identity, Rapport and Dawson call "for the anthropological appreciation of 'home' as a useful analytical construct" to "explore physical and cognitive movement within and between homes, and the relations between the two," incorporating perspectives of both the individual and the collective. ${ }^{14}$

According to Rapport and Dawson, the traditional fixed meaning of home discussed earlier is no longer useful in a world defined by mobility. Home has become mobile and "plurilocal," intricately bound up with movement, and can be defined as "where one best knows oneself."15 It also has the strongest effect in its absence or negation, as in the case of migration or displacement.

In more recent transnational ethnographic work, scholars have explored the idea of having more than one home. ${ }^{16}$ Fog Olwig explains, "In the first sense, home is a concrete locus of specific relations of social and economic rights and obligations ... in the second sense, home is a more abstract entity of belonging expressed through various types of narratives and other forms of symbolic interchange." These two understandings and practices of home "mutually reinforce and implicate one another."17 Mand similarly argues that home is a lived experience and a place of origin. ${ }^{18}$ It is this idea of two homes that I will explore here.

\section{Historical Context: Expellees and Refugees in Germany after the Second World War}

The mass displacement of people that followed the end of the Second World War was the birth of the refugee. ${ }^{19}$ Discussions about "refugees" and "displacement" have numerous underlying assumptions. Two major premises are "that refugees are a transitory phenomenon of crisis and disorder, and thus only temporarily relevant ... [and that] human nature is best served in a sedentary setting." ${ }^{20}$ The term displacement itself assumes a natural association between people and place that is being disrupted. ${ }^{21}$ In this politics of space the "essential refugee" must have crossed a national border.

The end of the Second World War saw one of the biggest forced movements of people in recent history, where "some 15.4 million people had to leave their former home"22 and move from Eastern to Western Europe. This was as a result of the newly drawn borders in postwar Europe which were agreed at the Yalta and Potsdam conferences. Germany lost significant territory to Poland, thus having to resettle its citizens within the new national boundaries. The borders of the four Occupation Zones were also agreed at these conferences, eventually leading to the West and East Germany split.

The largest of these movements was that of ethnic Germans to the four Occupation Zones in Germany. ${ }^{23}$ The expellees came mainly from Silesia, Pomerania, Sudetenland, and East Prussia in Eastern and Central Europe. Further movements occurred across other boundaries in Central and Eastern Europe-often overlapping-and there were large numbers of other displaced persons as well, ${ }^{24}$ such as ex-prisoners of war and German ex-soldiers. The proportion of people moving was significant, and refugees made up 16.2 per cent of the population of Germany in 1950. ${ }^{25}$

\section{Methodology}

The narrative and autobiographical approach was chosen for this research, because of participants' age and stage in life (elderly, recollecting experiences of fifty years ago). Furthermore, given the lack of visibility of this topic, this method is appropriate when writing about "history from below," highlighting experiences that have featured little in mainstream 
narratives. ${ }^{26}$ Finally, as Ahmadi Lewin argues, "Personal experiences are crucial for understanding how people perceive the meaning of home," thus the methodology used needs to be able to capture them. ${ }^{27}$

It has been argued ${ }^{28}$ that the strengths of the narrative approach lie in its ability to capture complexity and subjectivity, and to contextualize the individual's story. Importantly, this approach attempts to reveal the complexities of the individual's experiences as embedded in the broader context. As Abu-Lughod has argued, "Attending to the particulars of individuals' lives need not imply disregard for forces and dynamics that are not locally based, the effects of extra local or long-term processes are always manifested locally and specifically." ${ }^{29}$ These narratives are also "conscious and structured accounts of events across the past" 30 and reflect only what the expellees chose to tell me, thus generalizability is limited. While cultural positioning and narrative-construction biases cannot be eliminated, I tried to be constantly reflective and aware, to the extent possible, of the constructions and representations at play. Despite a small number of participants $(N=7)$, the qualitative and in-depth nature of narrative interviews can still provide useful insights into the social life of participants and how a particular historical event is remembered and was a real lived experience, revealing it also as a mundane and everyday experience. The aim is not representativeness but a deep understanding of dynamics and people.

While focusing in this article on the micro-level of individuals' experiences, it does so in the context of people's specific situated-ness in their political-economic and historical context, structural features, and policies. The aim is then to "understand one person's life and its meaning to that person in the context of broader history and culture" and to see what historical events of migration actually "look like on the ground," remaining "mindful both to the general and the particular." 31

The interviews were carried out in Germany in July 2012 as part of a postgraduate research project. Participants were found through personal networks and the Alliance of Expellees Bremen. All but one of the interviews were carried out in the participants' own homes and lasted between one and four hours. Two interviews were carried out with two participants present, at their request. This arrangement is likely to have affected the narratives, on the one hand as memory aids, on the other by not broaching certain sensitive topics, such as marriage or childbirth in the case of the brother and sister. Being bilingual in German and English, I conducted the interviews in German. They were also recorded and transcribed verbatim. Pseudonyms were used throughout to protect participants' identity. The analysis was carried out on German transcripts, using a grounded theory approach.

The majority of participants welcomed me and were forthcoming in sharing their life stories. However, some were reticent to revisit their past, often a painful memory. Their hesitancy was usually be expressed with silence, and in these instances I refrained from pressing for further information, reiterating to participants that they did not have to tell me things they did not want to, and that they could withdraw from the study at any point.

In addition to the interviews, I visited local archives in Diepholz and in Bremen, to gain a better historical understanding.

\section{The First Phase: Loss of "Home"}

The loss of the childhood and family "home" was a traumatic experience for expellees, and with it "the sense of belonging to a place and community [was] brutally disrupted." 32 Their narratives kept returning to this event. What effect did the loss have on their understanding of "home"? How does this past "home" influence the construction of "home" today?

Renate illustrates the strong feelings this memory provokes: "When I think of it today ... this anger, this extreme disappointment, it sits so deep, I think I will take these feelings to the grave with me ... You see, we did not just lose our house ... we lost our Heimat. You know, everything can be replaced, but not the Heimat."

The first movement west occurred during the war, fleeing from the advancing Soviet army. Often these first refugees had relatives in the West-both Julia and Renate made their way west in this way. Others returned to their homes after the front had passed them. This was the situation for Erhard, Herbert, Helga, and Maria. Returning home after this short flight was coloured in contradictory feelings: relief that their house was still there coexisted with the sadness at its damage.

Soon the situation changed again. Herbert und Helga were eleven and nine when they saw a lorry pull into their farmyard bringing two Polish families to live with them in their home, which already housed a family of five.

Already at this stage the expellees' understanding of "home" changed. First, there was the experience of the sudden loss of their physical home, their material possessions, and their labour on the fields. This was followed by the reappropriation of the home. However, after the return, "home" no longer had the same meaning, as the sense of security previously bound up with it was lost. The home, although in the exact same place, was now marked by the scars of the war. The visible damage to the house and the field was a constant reminder of the fragility of the home. 
The familiar village environment and everyday life had also been disrupted.

The arrival of Polish families means that the family home had to be shared. This again exposed the home as an unsafe and unfamiliar place. The home, which had been a private space, had to be given over almost entirely to strangers with whom they did not even share a language. The context of the war meant that, in the space of the home, a microcosm representing the postwar positions of "the Germans"-the losers-and "the Polish"- the winners-was being recreated. The result was a delicate balance that ensured survival for all members of the household, all who as a consequence of the war were losers of their own homes.

This period ended abruptly for most families as they were ordered to permanently leave between 1945 and 1947. They were told to pack their bags and go, destination unknown: "When we were leaving the village a little boy asked his grandfather, 'Where are we going?' and his grandfather answered, "If only I knew"” (Erhard).

Few realized that they would never return to their homeland, as illustrated by the fact that many buried their valuables before leaving. They were taken to a camp for medical screenings and delousing and then to their new "home." However, their final home still lay years away.

A consequence of the expulsion was the dispersal of families and village communities, representing the loss of another aspect of "home." In the homeland, families and neighbours depended on each other in their everyday life. Hermine tells of how they used to take their bread and cake to the bakery to be baked. And Maria writes in her memoirs, "We hadn't thought of the fact that we wouldn't be among the people we loved, once we had crossed the Neisse River. Where was Grandmother, Aunt Marta, the neighbours from home?" "They were deprived of the support networks they had relied on in their homeland," 33 which constituted a significant part of what "home" meant to expellees. It is then a loss of home in its multidimensional aspects-house, family, and social relationships.

In the movement of people from East to West, "the refugee camp became emplaced as a standardized, generalizable technology of power in the management of mass displacement." 34 It was not only the organization of people in the camps but also the German bureaucracy and new laws ${ }^{35}$ that created the category of the "refugee" and later "expellee." As Malkki puts it, "The refugee' as a specific social category and legal problem of global dimensions did not exist in its full modern form before this period." 36 Lehmann similarly observes that the fate of the refugee was seen as homogenous and uniform, when in reality the differences were more than the similarities. ${ }^{37}$ Such generalization and homogenization demonstrates a language of power that essentializes.
The term refugee was not the only categorization. With the realization that the "refugee problem" was not temporary and the German expellees and refugees had to be fully integrated in the Federal Republic of Germany (FRG), the term expellee emerged, illustrating the transition of their status to permanent members of the FRG. ${ }^{38}$

From these legal categorizations developed a collective identity of an otherwise diverse group of people bound together by their status as refugee/expellee and their common experiences of loss and suffering. It is this collective suffering, Svašek and Wolff argue, that is an important source of identification, individually and collectively. 39

The terminology employed by the bureaucracy, the rhetoric used by expellee organizations and expellees themselves, entrenched the experiences of loss and suffering in their collective and individual identities, and thus became key to their understanding of home.

The meaning of home underwent profound changes as a result of disruptions during this phase of loss. Home as a locally bounded place of security and familiarity was fundamentally undermined by the traumatic uprooting of people from their material and territorial home. Sharing homes with the Poles represented a shift from understanding the home as private to public. With these deep disruptions to expellees' understandings of home, how was home reinscribed with meaning?

\section{The Second Phase: Itinerancy and Surviving in the "Home" of Others}

After damage to many of Germany's towns and cities during the war and the consequent housing shortage, expellees were located mostly to the countryside, where many "had to endure deplorable housing conditions." 40 The destinations of expellees were usually set arbitrarily, and "the task of integrating almost 8 million dispossessed refugees into an economy still recovering from the impact of the war was enormous." 41

Most arrangements for the accommodation of expellees were made locally. After the journey in the refugee mass transports, they were commonly placed in temporary shelters until they were "billeted with private householders." 42 The housing conditions and length of time spent in these "temporary" arrangements varied and led to serious overcrowding. Throughout this period refugee living conditions were significantly worse than those of the indigenous inhabitants. ${ }^{43}$ As Herbert and Helga described the first accommodation they stayed in together with their parents, "The room we stayed in was just a small booth ... It was one room with just one bed in it, an oven, a round iron stove, for all four of us."

Among my interviewees the length of time spent in such housing arrangements varied from a few years to a decade. 
The housing shortage continued for a long time, with a shortage of 4.4 million homes in 1950.44

The experiences of the expellees I spoke to were typical of this period and deeply affected their understanding of home. The lack of privacy as subtenants was one major influence. Helga tells how their living space was constantly being "invaded" by their hosts: "When they, the farmers, opened the door to the entrance hall, we got completely smoked out!" Herbert did not even share the room with his family, instead he slept "in the entrance hall, where they put up an old bed for me to kip in, together with the farm hand." Hermine recalls a similar situation when they were subtenants with one small child: "As a baby she was all black in the face ... when ... [the landlords] were building the chimney and the wind came up, all the soot blew ... those are times you don't like to be reminded of."

Such conditions and multiple, frequent changes of "home" led to "home" being little more than a physical, practical arrangement. This "home" comes nearly without privacy, familiarity, or security-or these "homes" have none of the characteristics that the home in the Heimat had. Home then was starting to be constructed with reference to the absent Heimat, which also became idealized and romanticized.

Such an idealization of the homeland is common in migration and displacement. 45 In her study of Sudeten Germans, Svašek found that "Heimat was used to express Romantic notions of unspoiled life in the countryside" and explains that "selective memory is inherent in the notion of Heimat itself," erasing any problems and anomalies. ${ }^{46}$ Cordell found similar notions in his research, leading to difficulties in coming to term with the present. ${ }^{47}$ As Lovell argues, "memory recovers time and space in a synchronic gesture, streamlining and unifying some of its diversity and contradictions in order to create viable and cohesive collective images in the present." 48

Another pattern typical of the early postwar period was the separation of families through housing and work arrangements, in addition to dispersal created by the war and expulsion. The experience of Herbert and Helga's family offers an illustration. Their eldest brother, sixteenyear-old Michael, was immediately placed as a farm hand, and he lived where he worked. Once Herbert left school, he also moved out of his parents' sublet room to wherever he worked. On turning fourteen, Helga was "shipped to work in a hospital in Dortmund," also working for room and fare. Here, the dwelling of home is further disassociated from familiarity and security as the expellees' closest social relationships are removed from the space of the home. Home shifts from being an actual, bounded space to being de-localized relationships spread over significant physical distances.
Relations with locals also affected the way expellees understood home. These were often tense mainly as the result of economic discrepancies, such as in housing: "There is general agreement that housing was the most divisive economic issue between the newcomers and the original population." 49 Food was another cause, as is vividly recalled by Helga: "I will never forget how we were scolded by a local farm lady when we were stealing potatoes." It was particularly in rural areas that relations were difficult, "partly [as] the result of the huge economic and social gulf between the native and refugee populations. Many of the villages to which the refugees were sent in 1945-46 had emerged virtually unscathed from the war ... On the other hand, the refugees had to rebuild their lives from scratch. They had lost their homelands and most of their possessions." 50 This economic gulf is illustrated by a story from Herbert: "When I was staying with the farmer, we both got the same suit, a tailor in a nearby village made them. We both had the same suit, the only difference was that the farmer wore his for work and I only on Sunday afternoons. But I also had a suit!"

This time was narrated as a life of hardships and suffering, leading to feelings of inferiority and victimization among many expellees, strengthening the pillar of the collective identity developed through the loss of the home.

Finally, the view that the "refugee problem" was temporary caused tension. For some it became certain that they would never be able to return to their homeland only when Chancellor Kohl recognized the Oder-Neisse line as the German-Polish border in October 1990.51

These now semi-permanent arrangements reaffirmed the loss of home and second-class status among expellees. The space that was their "home" was often a space in the middle of another's home, constantly invaded by the host family. Whether relations were good or bad between the local family and the expellees, the negation of what home used to mean during this period entrenched the home in the Heimat as the ideal.

Even Renate, who managed to secure a private living space in a barrack with her mother and sister, expressed feelings of estrangement and inferiority: "I still have many inferiority complexes today. I felt foreign-which they also made me feel-it makes sense ... because they had remained in their Heimat ... but we were foreign. We felt as if we were intruders." We can see that it was not just the physical space that prevented feeling of being at home, but also the material hardships, lack of social networks, and myth of the eventual return to the homeland.

This phase of itinerancy was characterized by the dispersal of families, impermanent housing, accommodation in other people's homes, economic deprivation, and lack of privacy. Separation from families and friends, as well as 
difficult relationships with hosts meant that they did not feel at home in the house they lived in. This period further entrenched the separation of the material house from the emotional home and led expellees to romanticize and idealize the image and memory of their home in the homeland, both still having the potential of being their permanent future home. "Home" then became constructed in terms of what "home" meant in the homeland and in opposition to what it represented in the early postwar period. The combination of a forced loss of the home and continuous hardships in West Germany entrenched this dream. Underlying it was a sense of ambivalence. Despite all the hardships, many were able to see that in the context of the war and the horrors of the Holocaust, they had been lucky. As Gardner argued, the "presence of emotions depends to a huge degree on the personal histories and characters of the individuals concerned," which can result in ambivalent feelings. ${ }^{52}$ How then did expellees integrate their two notions of home?

\section{The Third Phase: Settlement and Making a New "Home'}

The housing situation of expellees improved considerably in the 1950 s as the result of the housing-building programs of the FRG (laws passed in 1950 and 1956), the 1952 Equalization of Burdens Law, foreign aid, and the "economic miracle." Furthermore, as Connor argues, the large proportion of expellees renting, buying, or building their own home reflected their "disinclination to be subtenants, resulting from the problems many had experienced when billeted with native householders in the early post-war years. Instead they preferred their own space and privacy." 53 In the early 1950 most of the new housing was intended as cheap rented accommodation; in the later 1950s the emphasis shifted to building for ownership. Despite these improved housing conditions for expellees, the census of 1960 still recorded a gap between the housing situation of expellees and that of the native population, which was not closed until 1968.54

With the passage of time, many of the expellees became accustomed to their new surroundings, and the age and stage of their life course meant that many were starting families. Finally, the Cold War made a return to the homeland less likely and the "economic miracle" in Germany made staying more appealing. Eventually, many expellees recognized that they would have to accept their new location and started making their house into their home.

Eventually expellees became embedded in their new locality and problems faded into the background. As Helga explained, "It was only in the early period that they [the locals] sort of rejected the refugees a bit, but then it was oK." The embedding included increased economic security as expellees found permanent employment and pursued careers. Joining local clubs and associations was another important marker for establishing expellees' sense of belonging in their new home.

Most important though was the re-establishment of social relationships, in which local expellee organizations played a significant role. Political aims of reclaiming the homeland lost relevance during the Cold War, and social events brought expellees together, creating from their shared imagined identity, that was defined by loss and suffering, a real community, a network of support in the new environment. Everyday life also brought locals and expellees closer together, through work, as neighbours or children attending the same schools. Renate, for example, became close friends with a colleague of her husband and his wife, to the extent that they would go on holiday together. Erhard became close friends with his neighbours through their children. The next generation found it significantly easier and were often determined to integrate. Mixed marriages between locals and expellees, but also expellees from different areas of origin, were common. "Since the end of the 1960s and the early 1970 s a break in the historical consciousness among the younger generation is observable." 55

The passage of time meant the creation of new families, as those who were children or young adults during the expulsion became adults and started a new stage in their life course. Especially the birth of children created a sense of belonging to the locality and a departure from a life defined by hardship. As Maria explains, "Soon our first daughter was born. She brought cheerfulness into our life. It was a gift from God."

With starting a new family came the desire for a physical and private space, which had now become a realistic possibility. Although this process was often long, in the majority of cases it led to expellees being able to own their own home, and, importantly, have privacy. Among the interviewees all but one were able to own their home. For Maria and her husband it was an especially long journey: "It took twelve years until we got our own house." In order to build housing, parishes had to find land as well as raw materials, which remained scarce. The result was often separate estates for expellees rather than individual houses integrated into towns and villages. Maria lives in such an estate to the north of Bremen. The result was clear territorial and spatial separations between locals and expellees. For Maria this was a positive experience: "After we built [our house] we were only among refugees, that was splendid!" To some extent it is here that the Heimat and the new home are combined, by creating a community of expellees only and recreating many aspects of the "life back home" such as subsistence farming. What binds this community together remains their common experience of loss and suffering, rather than their origin. In Maria's estate, for example, expellees came 
from Bessarabia, Silesia, and Pomerania, as well as smaller numbers from other areas.

In her study of the Sudeten Germans in Bavaria, Svašek also found narratives of ownership and property compensating for their earlier losses..$^{6}$ The house in its materiality, Mand further argues, acts "as a site for claims and counterclaims of belonging." 57 Home and house thus become reintegrated.

Visits back to the homeland organized by expellee organisations also became common during this time and led to another important realization about expellees' previous homes: their memory of the Heimat no longer corresponded with its current reality. Their home in the Heimat no longer existed and could not be connected to the current geographic location. Although it was often painful for expellees to see new generations being born in "their" home, they also realized that this was not their home anymore. Instead, theirs was the home of their memory and now only existed in the past. George and Fitzgerald, Andrew Demshuk and Svašek found similar effects of such visits in their respective research: "The homeland was no longer home." 58

In this period many aspects of expellees' initial economic deprivation and markers of difference disappeared. Combined with the dwindling prospects of a return to their homelands, many expellees accepted the likelihood that they would remain in their "home by chance" permanently. This acceptance also altered the way expellees understood the physical space of home: once again the aim was to combine the house with the home, to establish in it feelings of security, familiarity, and privacy. This period represented a conscious effort by the expellees to fix their home into place. However, the memory of their Heimat and expulsion meant that they were not able to be completely and exclusively connect emotionally to their new home.

\section{Remembering and Narrating Home and Heimat}

I always say I am at home here, but my Heimat is Pomerania. It's been like this thus far, it will always be like this. That will never change. The way in which we left our Heimat was too painful for it to be any other way. It would be different if I had left voluntarily ... but if you are forced ... (Renate)

Well, here I am Zuhause [at home], because I have my children here, but I always say if I visit Silesia and I die there, then bury me there in the Lichter forest, don't bring me back ... Of course, my roots are there, that's just how it is. (Maria)

Renate and Maria illustrate how expellees have constructed home as a consequence of their experiences. They maintain connections to both their home prior to the
expulsion-Heimat-and their new home, locality, and house. Like transnational migrants, expellees integrate two homes. The main difference here is that one home is an imagined home of the past, preserved in memory. It is integrated into the second home, which is physical and current, creating a fluid relationship between the two. Each remains internally bounded and fixed in meaning and locality. Svašek 59 and Cordell similarly found multiple constructions of home in their respective research, leading Cordell to argue that such an association represented "a certain schizophrenia" in feelings towards home. ${ }^{60}$

In a transnational context, Gardner also found multiple meanings of home being negotiated by her Bengali research participants, who integrated home as both "an idea and a set of social relationships and practices." 61 Similarly expellees enmeshed their idea of Heimat with their social relationships and practices making up their new home.

Gardner argues that imaginings of home are "not stable; [they are] a product of personal and collective histories and change over time."62 Although that happens for expellees, their idea of the imagined Heimat eventually becomes fixed: Heimat remains in the past, and it is only the past home that is associated with Heimat, not its current geographical location. Expellees cannot physically return to their Heimat as it no longer exists. It is because of their displacement, loss, and feelings of homelessness over a long period of time that the image of Heimat becomes idealized, romanticized, and fixed. As Ahmed argues, it is the impossibility of return that combines places and memories and binds them together. ${ }^{63}$

Together with the notion of having "two homes," feelings of contradiction and ambivalence develop. As Gardner found, "migrancy and exile involve constant quarrel with where one comes from" and change over the life course. Ahmadi Lewin further makes the point that "for elderly immigrants, the meaning of home takes on a special character involving not only the fact that they have lost their homeland and former residence but also their history and home." 64 Renate referred to this loss of their history: "It is so important in life to have some foundations on which you can build ... and that was exactly what we had lost." For Maria this was also important. She elaborated on her research into her family's history and their home in Silesia that went back to the eighteenth century.

Additionally, Heimat remains important because the economic hardship experienced in the early postwar period still affects their feelings of acceptance fifty years later. ${ }^{65}$ In her study of Moroccan women's transnational lives, Salih also found that "the reason why [they] keep emotionally and economically investing in their country of origin [is] the social and economic marginalization they experience in the host country." 66 
However, places are not just "constructs" in the imagination. They are also materially constituted locations. ${ }^{67}$ As Fog Olwig argued, home is not just an abstract space but a place of rooting, a set of practices, repetitions of social interactions, and the house itself. ${ }^{68}$ Gaining ownership of the material house or flat produced a process of rooting and belonging, in which the house became a home. Space becomes "reterritorialized" and the new territory becomes reinscribed with Heimat, shaped by the experiences of the expulsion, the loss, and the itinerancy of the early postwar period. The boundaries between the here (new home) and the there (Heimat) thus become blurred. The "there" that is the Heimat is no longer a real place, but an imagined place fixed in a past time and location and can exist only there However, Heimat can no longer be a real place because its inhabitants have been displaced, and Heimat now becomes part of the "here" in the imagination of the expellees, as well as in their everyday practices (engaging in subsistence farming, attending Heimat events) and in their social networks (a large majority of which are also expellees or refugees). The new home here and in the present is then always inscribed with the Heimat of the past there.

\section{Conclusion}

The aim of this article was to explore the meanings of "home" in relation to the experiences of German expellees following the Second World War. This mass displacement of people across Europe as the result of the war produced upheaval and disruption in the lives of millions. Although the expellees, refugees, and locals were all ethnic Germans, the experiences of loss and suffering, the housing arrangements of the early postwar period, and Germany's economic deprivation created strong attachments to Heimat among expellees.

Through narrative interviews with expellees this article identified three phases of change for the home: the loss of home, a period of itinerancy, and settlement. These phases significantly affected how expellees understand home. Despite the great separation between them and their Heimat through time and space, their feelings and memories about Heimat have remained strong. They were entrenched by the brutal loss, as well as the difficulties expellees experienced in their new destinations. Heimat has thus become the idealized and romanticized notion of the past and unchanged home. Eventually most expellees accepted that their homeland would not belong to Germany again. The longer they stayed in their new location, started families and careers, the more they belonged to their new communities.

The combination of the expellees' strong feelings for their Heimat and the eventual settlement in their new home made the meaning of home a concept full of contradictions and ambivalence. Home was not just a multidimensional concept, but to expellees it had two quite distinct fixed meanings, which stood in a constant influencing and fluid relationship to each other. Throughout all the narratives there was a very matter-of-fact approach towards this complexity and with it an acceptance that "this is just how it is."

The numbers of expellees are declining as they reaching the end of their lives, and their experiences will be lost if they are not captured. The difficulties they went through are just as much part of the German historical narrative as is the narrative of the "successful" integration of expellees and refugees and the war itself. The ability of expellees to look back on their experiences at the end of their lives from a secure and comfortable position can give us valuable insights into what forced displacement and reterritorializing a home can mean. Further exploration in the context of a globalizing world, increasing numbers of refugees worldwide, and Germany's place as a receiving country for increasing numbers of refugees today could help us develop an understanding of the challenges facing refugees in their host countries.

Vanessa Hughes is a PhD student at Goldsmiths, University of London. The author may be contacted atv.hughes@gold. ac.uk.

\section{Notes}

1 I. Connor, Refugees and Expellees in Post-war Germany (Manchester: Manchester University Press, 2007); A. Lehmann, Im Fremden ungewollt zuhaus. Flüchtlinge und Vertriebene in Westdeutschland 1945-1990 (Münich: C.H. Beck, 1991); P. Ther, "The Integration of Expellees in Germany and Poland after World War Two: A Historical Reassessment," Slavic Review 55, no. 4 (1996): 779-805.

2 L.H. Malkki, Purity and Exile: Violence, Memory and National Cosmology among Hutu Refugees in Tanzania (Chicago: University of Chicago Press, 1995), 2.

3 Lehmann, Im Fremden ungewollt zuhaus.

4 For example, see A. Demshuk, The Lost German East: Forced Migration and the Politics of Memory, 1945-1970 (New York: Cambridge University Press, 2012); and M. Svašek, "Narratives of 'Home' and 'Homeland': The Symbolic Construction and Appropriation of the Sudeten German Heimat," Identities: Global Studies in Culture and Power 9, no. 4 (2002): 495-518.

5 Lehmann, Im Fremden ungewollt zuhaus; R. Schulze, "The Struggle of Past and Present in Individual Identities: The Case of German Refugees and Expellees from the East," in Coming Home to Germany? The Integration of Ethnic Germans from Central and Eastern Europe in the Federal Republic, ed. D. Rock and S. Wolff, 38-55 (New 
York: Berghahn, 2002); M. Svašek, "The Politics of Chosen Trauma: Expellee Memories, Emotions and Identities," in Mixed Emotions: Anthropological Studies of Feeling, ed. K. Milton and M. Svašek, 195-214 (Oxford: Berg, 2005); Svašek, "Narratives of 'Home' and 'Homeland': The Symbolic Construction and Appropriation of the Sudeten German Heimat," Identities: Global Studies in Culture and Power 9, no. 4 (2002): 495-518.

6 K. Cordell, "The Past, the Present, and Virtual Reality: A Comparative Assessment of the German Landsmannschaften," Journal of Baltic Studies 37, no. 1 (2006): 22-47; S. Wolff, "German Expellee Organizations between 'Homeland' and 'At Home': A Case Study of the Politics of Belonging," Refuge 20, no. 1 (2001): 52-64.

7 M. George and R.P. Fitzgerald, "Forty Years in Aotearoa New Zealand: White Identity, Home and Later Life in an Adopted Country," Ageing \& Society 32 (2012): 239-6o.

8 A. Gupta and J. Ferguson, "Beyond 'Culture': Space, Identity, and the Politics of Difference," Cultural Anthropology 7, no. 1 (1992): 6-23.

9 See, for example, F.A. Lewin, "The Meaning of Home among Elderly Immigrants: Directions for Future Research and Theoretical Development," Housing Studies 16, no. 3 (2001): 353-70; Svašek, "Narratives of 'Home' and 'Homeland."'

10 K. Gardner, Age, Narrative and Migration: The Life Course and Life Histories of Bengali Elders in London (Berg: Oxford, 2002), 211.

11 S. Mallett, "Understanding Home: A Critical Review of the Literature," Sociological Review 52, no. 1 (2004): 62-89. 12 Ibid.

13 See, for example, Gardner, Age, Narrative and Migration; K. Fog Olwig, "A Wedding in the Family: Home Making in a Global Kin Network," Global Networks 2, no. 1 (2002): 205-18; Fog Olwig, Caribbean Journeys: An Ethnography of Migration and Home in Three Family Networks (Durham, NC: Duke University Press, 2007); R. Salih, Gender in Transnationalism: Home, Longing and Belonging among Moroccan Migrant Women (London: Routledge, 2003).

14 N. Rapport and A. Dawson, "The Topic and the Book," in Migrants of Identity: Perceptions of Home in a World of Movement, ed. N. Rapport and A. Dawson (Oxford: Berg, 1998), 4.

15 Ibid., 9.

16 See, for example, S. Ahmed, "Home and Away: Narratives of Migration and Estrangement," International Journal of Cultural Studies 2, no. 3 (1999): 326-47; Gardner, Age, Narrative and Migration; Fog Olwig, "Wedding in the Family"; Fog Olwig, Caribbean Journeys; George and Fitzgerald, "Forty Years in Aotearoa New Zealand"; K. Mand, "I've Got Two Houses, One in Bangladesh, One in London, Everyone Has: Home, Locality and Belongings," Childhood 17, no. 2 (2010): 273-86; Salih, Gender in Transnationalism.

17 Fog Olwig, "Wedding in the Family," 216.
18 Mand, "I've Got Two Houses."

19 L.H. Malkki, "Refugees and Exile: From 'Refugee Studies' to the National Order of Things," Annual Review of Anthropology 24 (1995): 495-523.

20 B. Harrell-Bond and E. Voutira, "Anthropology and the Study of Refugees," Anthropology Today 8, no. 4 (1992): 7.

21 F. Stepputat, "Repatriation and the Politics of Space: The Case of the Mayan Diaspora and Return Movement," Journal of Refugee Studies 7, nos. 2/3 (1994): 175-85.

22 H. Fassmann and R. Munz, "European East-West Migration, 1945-1992," International Migration Review 28, no. 3 (1994): 521.

23 Connor, Refugees and Expellees; Ther, "Integration of Expellees in Germany and Poland."

24 See, for example, A.R. Seipp, "Refugee Town: Germans, Americans, and the Uprooted in Rural West Germany, 1945-52," Journal of Contemporary History 44, no. 4 (2009): 675-95.

25 Connor, Refugees and Expellees, 174.

26 A. Thomson, "Moving Stories: Oral History and Migration Studies," Oral History 27, no. 1 (1999): 24-37.

27 Lewin, "Meaning of Home among Elderly Immigrants."

28 A.M. Findlay and F.L.N. Li, "An Auto-biographical Approach to Understanding Migration: The Case of Hong Kong Emigrants," Area 29, no. 1 (1997): 34-44; A. Thomson, "Moving Stories: Oral History and Migration Studies," Oral History 27, no. 1 (1999): 24-37; M. Chamberlain and P. Thompson, eds., Narrative \& Genre: Contexts and Types of Communication (New Brunswick, NJ: Transaction Publishers, 1998).

29 L. Abu-Lughod, Writing Women's Worlds: Bedouin Stories, (Berkeley: University of California Press, 1993), ACLS Humanities e-book.

30 Gardner, Age, Narrative and Migration, 31.

31 C.B. Brettell, Anthropology and Migration: Essays on Transnationalism, Ethnicity, and Identity (Walnut Creek, CA: Altamira, 2003), 25, 32, 44.

32 Wolff, "German Expellee Organizations," 53.

33 Connor, Refugees and Expellees, 165.

34 Malkki, "Refugees and Exile," 498.

35 For example, the 1952 Lastenausgleichsgesetz (War Burden Redistribution Act) and the 1953 Bundesvetribenengesetz (Federal Expellee and Refugee Law). Wolff, "German Expellee Organizations," 55.

36 Malkki, "Refugees and Exile," 497-8.

37 Lehmann, Im Fremden ungewollt zuhaus, 20.

38 Ther, "Integration of Expellees," 781.

39 Svašek, "Narratives of 'Home' and 'Homeland"; Wolff, "German Expellee Organizations."

40 Connor, Refugees and Expellees.

41 Ibid.

42 Ibid., 30-1.

43 Ibid., 32.

44 Ibid., 139-40. 
45 See, for example, Gardner, Age, Narrative and Migration; George and Fitzgerald, "Forty Years in Aotearoa New Zealand."

46 Svašek, "Narratives of 'Home' and 'Homeland."

47 Cordell, "Past, the Present, and Virtual Reality."

48 N. Lovell, "Introduction," in Locality and Belonging, ed. N. Lovell (London: Routledge, 1998), 12.

49 Connor, Refugees and Expellees, 69.

50 Ibid., 64.

51 Schulze, "Struggle of Past and Present," 44.

52 Gardner, Age, Narrative and Migration, 18.

53 Connor, Refugees and Expellees, 140.

54 Ibid.

55 Lehmann, Im Fremden ungewollt zuhaus, 83.

56 Svašek, "Narratives of 'Home' and 'Homeland."

57 Mand, "I've Got Two Houses," 276.

58 George and Fitzgerald, "Forty Years in Aotearoa New Zealand," 251; and Svašek, "Narratives of 'Home' and 'Homeland."'
59 Svašek, "Narratives of 'Home' and 'Homeland," 498.

60 Cordell, "Past, the Present, and Virtual Reality," 41.

61 Gardner, Age, Narrative and Migration, 4.

62 Ibid., 23.

63 Ahmed, "Home and Away," 343.

64 Lewin, "Meaning of Home among Elderly Immigrants," 366.

65 Schulze, "Struggle of Past and Present," 44.

66 Salih, Gender in Transnationalism, 53.

67 Gardner, Age, Narrative and Migration, 218.

68 K. Fog Olwig, "Epilogue: Contested Homes: Home-making and the Making of Anthropology," in Migrants of Identity: Perceptions of Home in a World of Movement, ed. Nigel Rapport and Andrew Dawson, 225-36 (Oxford: Berg, 1998).

(C) Vanessa Hughes, 2016. This open-access work is licensed under a Creative Commons Attribution-NonCommercial 4.0 International License, which permits use, reproduction and distribution in any medium for non-commercial purposes, provided the original author(s) are credited and the original publication in Refuge: Canada's Journal on Refugees is cited. 